\title{
The function of integration of person in city companies Obregon
}

\section{La función de integración de personal en empresas de ciudad Obregón}

\author{
ORTEGA-ARRIOLA, Jorge† $\dagger$, BUELNA-PEÑÚÑURI, Ramiro Arnoldo and ÁLVAREZ- \\ RODRÍGUEZ, Alexis Leonel
}

Instituto Tecnológico de Sonora. Calle 5 de Febrero 818, Centro, Urb. No. 1, 85000 Cd Obregón, Son.

ID $1^{\text {st }}$ Author: Jorge, Ortega-Arriola / ORC ID: 0000-0001-7364-9159

ID $1^{\text {st }}$ Coauthor: Ramiro Arnoldo, Buelna-Peñúñuri / ORC ID: 0000-0003-3205-396X,

ID $2^{\text {nd }}$ Coauthor: Alexis Leonel, Álvarez-Rodríguez / ORC ID: 0000-0001-6169-7831,

DOI: $10.35429 / J L D E .2019 .4 .3 .7 .13$

Received February 10, 2019; Accepted June 5, 2019

\begin{abstract}
One of the company's needs nowadays is personal ideal according to the profile, which has been complicated by several factors. This work aims to identify companies that carry out a formal application phases of the process of integration of personnel. This is a research with a sample of convenience not probabilistic involving 50 companies of different turns of Ciudad Obregón. For the collection of data was used a questionnaire designed by experts from the administrative audit, which allowed to identify immediately the implementation of the basic elements that make the process of integration of personnel: recruitment selection, recruitment and induction. The importance of the project offers is that a picture of the implementation of the basic process of the integration of personnel in companies. In terms of the findings found that $36 \%$ reported not to carry out a process of personnel selection, another result is that $20 \%$ do not have a formal recruitment activity, $22 \%$ not performing activity of induction to the company and $18 \%$ does not a formal recruitment.
\end{abstract}

Recruitment, Selection, Hiring and induction

\begin{abstract}
Resumen
Una de las necesidades de la empresa en la actualidad es contar con personal ideal de acuerdo al perfil, lo que ha resultado complicado por varios factores. El presente trabajo tiene como objetivo identificar a las empresas que llevan a cabo una aplicación formal de las fases del proceso de integración de personal. Esta es una investigación con una muestra por conveniencia no probabilística en la que participaron 50 empresas de diferentes giros de Ciudad Obregón. Para la recolección de los datos se utilizó un cuestionario elaborado por expertos de la auditoría administrativa, el cual permitió identificar de manera inmediata la aplicación de los elementos básicos que integran el proceso de integración de personal: reclutamiento, selección, contratación e inducción. La importancia del proyecto ofrece es que un panorama de la aplicación del proceso básico de la integración de personal en las empresas. En cuanto a los hallazgos se encontró que el 36\% reportan no llevar a cabo un proceso de selección de personal, Otro resultado es que el $20 \%$ no tienen una actividad formal de reclutamiento de personal, el $22 \%$ no realiza actividad de inducción a la empresa y el $18 \%$ no realiza una contratación formal.
\end{abstract}

Reclutamiento, Selección, Contratación e inducción

Citation: ORTEGA-ARRIOLA, Jorge, BUELNA-PEÑÚÑURI, Ramiro Arnoldo, and ÁLVAREZ-RODRÍGUEZ, Alexis Leonel. The function of integration of person in city companies Obregon. RINOE Journal-Labor and Demographic economic. 2019. 3-4 : 7-13.

$\uparrow$ Researcher contributing first author. 


\section{Introduction}

This project arises from the need to identify causes for which companies in Ciudad Obregón may not be having efficiency in terms of the integration of personnel to it, therefore, the investigation was conducted to identify the application rate of basic elements of the function of integration of personnel in companies of Ciudad Obregón, so that obtaining the results of the same one can generate an action plan for both the company individually and in a group way through the business organizations. This project consists in its first with information that supports the performance of the work, in the second part (theoretical framework) it contains relevant information on each of the steps of the personnel integration process, the third part contains the methodology that led to In order to carry out the project, the fourth part mentions the results of the investigation and the fifth part contains the conclusions and recommendations.

This project arises from the need to identify causes for which companies in Ciudad Obregón may not be having efficiency in terms of the integration of personnel to it, therefore, the investigation was conducted to identify the application rate of basic elements of the function of integration of personnel in companies of Ciudad Obregón, in such a way that obtaining the results of the same one can generate an action plan for both the company individually and in a group way through the business organizations.

\section{Background}

Since the need to join together to work as a team and generate a benefit for the group arises, it has become necessary to integrate with the most appropriate people to generate workforce and achieve the expected results. In administration Reyes Ponce (2013), it indicates as an important part of the administrator's functions the integration of personnel, a function that unfortunately, a large part of the administrators, including book authors, minimize it by including it in the organizational phase of the administrative process. However, despite this situation, in any university where the Bachelor of Administration degree or related career is offered, courses related to the integration of personnel are offered within the curriculum.

\section{Problem Statement}

Competitiveness and productivity are results that depend on the workforce. Considering these elements as the basis for the development of any organization is where the company's staff takes special interest for the results sought. However, despite the efforts made to give special value to the workforce, it is not yet correctly understood from the point of view of impact on results. The lack of a clear structure and formal procedures for the integration of personnel into the company delays organizational efficiency and sometimes it is even considered a business as unprofitable due to the lack of results, which come from the work of the staff. On repeated occasions it is heard in the news and newspapers that the Mexican company does not have the efficiency of expected results and wonders what is happening? Therefore, the investigation is carried out and the next question is answered at the end of the project. Are the basic elements of the integration of personnel in the companies of Ciudad Obregón applied?

\section{Objective}

Determine the level of application of the basic elements of the staff integration function in companies of Ciudad Obregón with the purpose of generating actions according to the results obtained.

\section{Justification}

The need to compete and remain with liquidity of Mexican companies is increasing due to the entry into the market of goods and services from prestigious franchises that in addition to offering good products or services also offer better prices and in some cases better wages. In all this, the personnel that the company has and plays a very important role and therefore the process that is followed to integrate it. In Mexico, there is still a problem in recognizing the importance of personnel in relation to organizational objectives. (Financial, 2019). He points out that "one of the 10 mistakes that slow the growth of SMEs is to ignore the attraction of talent, that is: having a solid work team is the basis for starting a successful company. If people who do not fit the vision of the company are hired, the business will end up stalling and losing money due to the constant turnover of personnel, or the maintenance of incorrect equipment". 
The generation of results translated into profits is not just a matter of knowing how to sell or produce, it is more than just having the appropriate personnel to carry out the tasks necessary to achieve business success.

\section{Study delimitation}

The study was carried out in companies of different turns of Ciudad Obregón that are not franchises and whose size are medium to large and that are formally organized.

\section{Theoretical framework}

In this section, elements are explained that explain the phases of this from the concept of the integration of personnel and reasons that show the importance for the growth and development of the companies.

\section{Integration as a phase of the administrative process}

The administrative process contains the basic elements or stages in which the administrator takes them as the guiding axis of his administrative function, in such a way that, depending on the clarity and perception of the administrator, he is able to adapt to one of them considering from his point of View what you can consider as right or wrong. This depends a lot on the result that he can have as an administrator in a social organization, since in some way the concept can delimit his field of action or commitment with respect to the functions of the administrative process. It is necessary to emphasize that in order for a company to have a coordination and coherence in performance, it is necessary that the administrative stages that precede integration, such as planning and organization, are properly structured and defined, so that they serve as the basis for Personnel recruitment phase, in this, it is necessary to mention that there are different approaches in terms of the elements that make up the administrative process, in some the integration stage is mentioned and others do not specifically do so however, this function is included within any of the phases. Table 1 shows the administrative process of several authors of the administration.
It shows how the integration stage is considered within the administrative process. It can be considered that the recruitment of personnel begins when we review the job description that we are about to fill, since the information that is published is extracted from this document that said step comes from a formal design process of this.

\begin{tabular}{|l|c|l|}
\hline \multicolumn{1}{|c|}{ Author } & Year & \multicolumn{2}{c|}{ Administrative process } \\
\hline $\begin{array}{l}\text { Agustin Reyes } \\
\text { Ponce }\end{array}$ & 2013 & $\begin{array}{l}\text { Forecasting, planning and } \\
\text { organization, integration, } \\
\text { direction and control }\end{array}$ \\
\hline $\begin{array}{l}\text { Salvador } \\
\text { Mercado }\end{array}$ & 2011 & $\begin{array}{l}\text { Planning, organization, } \\
\text { direction and control }\end{array}$ \\
\hline $\begin{array}{l}\text { Weihrich, } \\
\text { Cannice } \\
\text { Koontz }\end{array}$ & 2017 & $\begin{array}{l}\text { Planning, organization, } \\
\text { integration, direction and } \\
\text { control }\end{array}$ \\
\hline Munch & 2010 & $\begin{array}{l}\text { Planning, organization, } \\
\text { integration, direction and } \\
\text { control }\end{array}$ \\
\hline $\begin{array}{l}\text { Robbins, } \\
\text { Coutler } \\
\text { DeCenzo }\end{array}$ & 2017 & $\begin{array}{l}\text { Planning, organization, } \\
\text { leadership and control }\end{array}$ \\
\hline
\end{tabular}

Table 1 The administrative process according to different authors

Note. Own elaboration taking the information from the various sources indicated

As can be seen in the Table, the number of phases contained in the administrative process will depend a lot on the vision and perception of the students of the administration. It is necessary to mention that the failure to consider integration as such within the phases of the administrative process causes the interest in the function to be less and therefore the steps that must be followed in order to achieve efficiency and effectiveness are not fully carried out. administrative management (Ponce, 2013). It is worth mentioning that in the processes in which it is not included individually if they consider it within any of the other phases.

\section{Integration concept}

The definitions and concepts about integration as part of the administrative process are very varied and coincidental at the same time, the important thing in this is the importance that the administrator gives to this phase of the administrative process and even the perception he has about it. 
This is because you can have a very clear concept of the definition, but the change is made by the vision or perspective you have about the function. It can be seen simply as a function that has to keep all the positions of the company covered or it can be seen as the responsibility to keep the ideal people in the positions, it can also be seen as a goal of the person in charge of fulfilling in time and time regarding the hiring of a new employee. Some integration definitions are:

According to Ponce (2013) "Integrating is obtaining and articulating the material and human elements that the organization and planning indicate as necessary for the proper functioning of a social organization".

According to Munch (2010). "Integration is the function through which the necessary resources are chosen and obtained to implement the decisions required to execute the plans in accordance with the organizational architecture".

As mentioned in the previous definitions, the authors emphasize the elements that are necessary to obtain for the proper functioning of the company and are: the human and material elements. This means that the Bachelor of Administration has an inherent and specific responsibility in accordance with the functions of any administrator that is to obtain or provide the company with the resources necessary for it to function properly. Here is the important thing to recognize integration as a special element in the administrative process. No administrator should lack the knowledge, tools and techniques necessary for the provision of both personnel and material resources to the company since they are actions that are considered strategic for the achievement of organizational goals.

\section{Importance of staff integration}

According to Casas (2016), he points out that beyond the economic, it is necessary to consider personnel as the most important factor to achieve success in a company. This is because it is the staff of an organization that makes things happen and neither material nor financial resources nor any resource can operate on its own without the intervention of the human factor.
The growth of every company will depend on the personnel it has. The company as an entity created to achieve the goals, whether lucrative or not, will always depend on the human factor. In the business sense we refer to the ideal staff to occupy a position in the company. (Dueñas, 2019) Point out that finding the right human staff that fits the organizational philosophy is not easy. Referring to the appropriate staff goes far beyond complying with a list of requirements that are established as the basis for considering a person as a candidate for a position. Information on the requirements that are requested for a given company can be found in the different media, however, it is very frequent that these requirements are only aimed at verifiable elements such as: level of studies, medical exam, knowledge exam and Verification of information contained in the request form.

\section{Elements of the integration phase}

According to the research we find four elements of the integration of people: Recruitment, selection, hiring and induction which are developed below. Recruitment. It consists of attracting interested people to the company to occupy a position and this is done by different means and sources. (Espinoza, 2012) refers that there are several sources to stock up on the best elements: Among others they can be: educational institutions, the church, other companies, the job bank and the same company. (Logistics, 2015) "The most important factors that drove organizations to adopt workforce management. The most important being the need for a more flexible workforce, which allows to have the right people in the right place and time in order to meet the demand, whether for production or services".

Carrasco (2017) Notes that: Hiring personnel without having an adequate job description can result in large losses for the company. Some of the negative effects are: low productivity, the cost of probable dismissal and loss of time, increase in staff turnover". 
Selection. In this process that consists of several steps, it is essential to mention that each of them must be carried out with professionalism, that is, whoever participates in this part must be a qualified person that is to say professionals who have preparation in these aspects, since this It implies vision, professional knowledge and experience. Generally, the nonhiring of a good candidate comes from the lack of professional knowledge and this has an impact on the company because a good element is no longer obtained. Some of the steps included in this part of the integration of personnel are: reception of job application, interview, application of tests, information research and medical examination.

Hiring This part of the staff integration process is intended to formalize the work relationship between the company and the candidate. However, a frequent situation is that the candidate is not given enough time to read the contract in which it is specified all the responsibilities that he contracts with the company including the salary to be obtained. The problem that arises when the employee does not have enough information regarding the days, hours, overtime, compensation and benefits, is that when the worker receives his first fortnight he tends to leave the job because he does not consider it sufficient to meet his needs, Even when you are retained in the company to cover overtime or when you go to the company on rest days, the disappointment on the part of the worker comes and this ends in abandonment of work. The lack of a formal employment contract has consequences for the employee and for the company. The Federal Labor Law states that this document is the responsibility of the employer. The obligation to have a contract applies to all types of formal employment. In the event that a review is carried out in the company by the inspection and it is detected that the workers work without a contract, the company will face a high fine, the lack of formal contract is also considered as a fraud to Social security and fines to which the company is credited for these legal omissions. (Legalario, 2019)

Induction. Induction as a last step in the recruitment process is too important since that is where the enthusiasm of the worker for the company should be given.
There are several means that can be used to perform this important step: a welcome manual in physical or digital, video, do it personally, let another employee of the company perform it. The importance of induction as it is said is where the employee falls in love with the company, and for this a very special attention is required towards the new worker, where he is made to feel the importance he has for the company and is made to feel valuable. This has a direct impact on the commitment it may have towards the activities entrusted to it. (Human Resources Blog, 2015) notes that: "The people who make up the work force of a company are the most important and valuable resource, so it is absolutely necessary to take care of it, stimulate it, train it and promote it as much as possible from the team of Human Resources of the company. Not even the machinery can be compared to the efficiency of the human mind since the true success of an organization always goes through the fact that the most appropriate human decisions are taken at all times."

\section{Method}

\section{Subject}

The subjects of the investigation were 50 regional and national Mexican companies of Ciudad Obregón of different types, from industrial, commercial, services and public organizations and non-profit organizations. The number of companies was based on their acceptance.

\section{Instrument}

A personnel integration questionnaire was used, which is part of the instruments used to perform administrative and operational diagnoses and which consists of 26 closed-ended questions, 10 multiple-choice questions, and 9 open-ended questions.

\section{Process}

To carry out the investigation, we first proceeded to make calls with managers and businessmen asking for their participation in this project. Once accepted by the employer, they proceeded to make visits to each of the companies to apply the survey. After the application, the information was concentrated, and the results were identified to finally graph. 


\section{Results and discussion}

\section{Results}

The results obtained in the application of the integration instrument are shown below. In recruitment it was obtained that $20 \%$ of the companies do not carry out a recruitment of personnel, their basis for the integration of personnel is "the door of the street", this means that if at the moment a person arrives to ask for work There is a vacancy you are hired without carrying out the other activities of the personnel integration procedure.

Regarding a personnel selection process, it was found that $36 \%$ of the companies do not have a formal selection process, however they only carry out one step of the process that is the interview with the candidate and generally the company manager does . In the contracting part it was found that 9 companies do not yet carry out a formal contracting, which puts them in a situation of legal vulnerability.

In the induction phase it was found that 11 of the companies have no idea what is the induction of the staff to the position or the company, in an interview it was answered that when the new employee arrives for the first time the company will only act and perform work that at that time you are being requested and so you will learn what should be done in the position assigned to you.

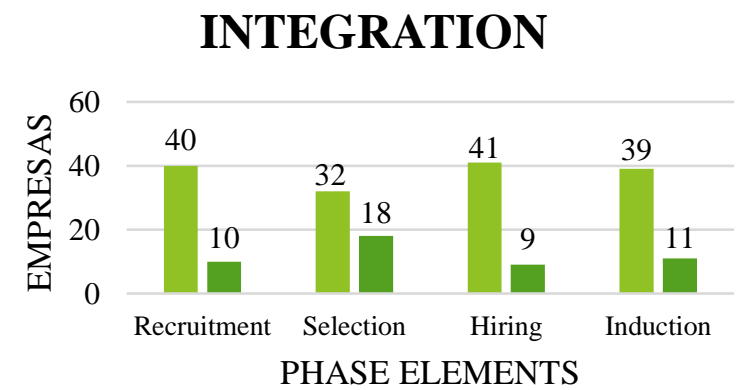

Exists Does not exist

Graphic 1

\section{Results of the application of the staff integration instrument}

\section{Discussion}

Considering the results obtained, it is detected that the administrative management of the empirical type still persists, with the focus that a person who holds the position of manager of the latter has enough vision to meet people and hire them taking into account their criteria at first sight. However, it should be mentioned that in all the companies investigated they have professionals from different areas including administrators, which is more worrying for the administrators' union.

\section{References}

Carrasco, L. (24 de 02 de 2017). HRTRENDS by empleo. Obtenido de http://empresas.infoempleo.com/hrtrends/conse cuencias-de-reclutar-de-forma-erronea

Casas, D. (25 de 08 de 2016). Acsendo.blog. Obtenido de https://blog.acsendo.com/valor-delcapital-humano-una-organizacion/\#

Dueñas, F. C. (16 de 06 de 2019). Acsendoblog. Obtenido de https://blog.acsendo.com/4razones-inesperadas-por-las-que-puede-perdersu-talento-humano/

\section{Espinoza, L. F. (2012). Administración de Recursos Humanos. México: Trillas.}

Financiero, E. (26 de junio de 2019). El Financiero. Recuperado el 26 de 06 de 2019, de https://www.elfinanciero.com.mx/pyme/10errores-que-frenan-el-crecimiento-de-laspymes-en-mexico

Heinz Weihrich, M. V. (2017). Administración Una perspectiva global. Mexico: McGraw Hill.

Legalario. (23 de 06 de 2019). Obtenido de https://www.legalario.com/blog/que-pasa-sitrabajo-sin-contrato/

Logística, É. (08 de 12 de 2015). Mejores prácticas y productividad en México. Obtenido de:

http://www.logisticamx.enfasis.com/notas/7387

4-mejores-practicas-y-productividad-mexico 
María Elena Camarena Adame, S. A. (2016). La Gestión Humana como clave para la competitividad. En M. E. Adame, Admiistración de los recursos humanos: Teoría y práctica innovadora (pág. 13). México: Publicaciones Empresariales UNAM .

Mercado, S. (2011). Administración aplicada Teoría y práctica. México: Limusa.

Munch, L. (2010). Administración, Gestion organizacional, enfoques y proceso administrativo. Naucalpan, Edo. de Mexico: Pearson.

Ponce, A. R. (2013). Administración de EMPRESAS Teoría y práctica Segunda parte. México: Limusa.

Problemas comunes en Recursos Humanos. (09 de 04 de 2015). Obtenido de http://blogderecursoshumanos.es/problemascomunes-en-recursos-humanos/

Robbins, C. y. (207). Fundamentos de Administración. México: Pearson. 